\title{
Gene expression of porcine blastocysts from gilts fed organic or inorganic selenium and pyridoxine
}

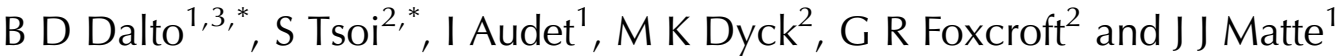 \\ ${ }^{1}$ Dairy and Swine Research and Development Centre, Agriculture and Agri-Food Canada, 2000 College Street, \\ Sherbrooke, Quebec, Canada J1M 0C8, ${ }^{2}$ Department of Agricultural, Food and Nutritional Science, \\ University of Alberta, Edmonton, Alberta, Canada T6G 2P5 and ${ }^{3}$ Department of Animal Science, \\ Universidade Estadual de Londrina, Londrina, Paraná 86057-970, Brazil
}

Correspondence should be addressed to J J Matte; Email: jacques.matte@agr.gc.ca

*(B D Dalto and S Tsoi contributed equally to this work)

\begin{abstract}
In this study, we determined how maternal dietary supplementation with pyridoxine combined with different sources of selenium (Se) affected global gene expression of porcine expanded blastocysts (PEB) during pregnancy. Eighteen gilts were randomly assigned to one of the three experimental diets $(n=6$ per treatment): i) basal diet without supplemental Se or pyridoxine (CONT); ii) CONT $+0.3 \mathrm{mg} / \mathrm{kg}$ of Na-selenite and $10 \mathrm{mg} / \mathrm{kg}$ of HCl-pyridoxine (MSeB $\left.{ }_{6} 10\right)$; and iii) CONT $+0.3 \mathrm{mg} / \mathrm{kg}$ of Se-enriched yeast and $10 \mathrm{mg} / \mathrm{kg} \mathrm{of} \mathrm{HCl}$-pyridoxine $\left(\mathrm{OSeB}_{6} \mathrm{10}\right.$. All gilts were inseminated at their fifth post-pubertal estrus and killed 5 days later for embryo harvesting. A porcine embryospecific microarray was used to detect differentially gene expression between MSeB $_{6} 10$ vs CONT, OSeB 610 vs CONT, and OSeB 10 vs $\mathrm{MSeB}_{6} 10$. CONT gilts had lower whole blood Se and erythrocyte pyridoxal-5-P concentrations than supplemented gilts $(P<0.05)$. No treatment effect was observed on blood plasma Se-glutathione peroxidase activity $(P=0.57)$. There were 10,247 , and 96 differentially expressed genes for $\mathrm{MSeB}_{6} 10$ vs CONT, $\mathrm{OSeB}_{6} 10$ vs $C O N T$, and $\mathrm{OSeB}_{6} 10$ vs $\mathrm{MSeB}_{6} 10$ respectively. No specific biological process was associated with $\mathrm{MSeB}_{6} 10$ vs CONT. However, for $\mathrm{OSeB}_{6} 10$ vs CONT, upregulated genes were related with global protein synthesis but not to selenoproteins. The stimulation of some genes related with monooxygenase and thioredoxin families was confirmed by quantitative real-time RT-PCR. In conclusion, $\mathrm{OSeB}_{6} 10$ affects PEB metabolism more markedly than MSeB $\mathbf{M}_{6} 10$. Neither Se sources with pyridoxine influenced the Se-glutathione peroxidase metabolic pathway in the $\mathrm{PEB}$, but $\mathrm{OSeB}_{6} 10$ selectively stimulated genes involved with antioxidant defense.

Reproduction (2015) 149 31-42
\end{abstract}

\section{Introduction}

During the last decades, marked increases in ovulation rate in pigs have been associated with reduced embryo survival (Freking et al. 2007, Patterson et al. 2008), possibly due to the poor quality of oocytes shed by these supplemental follicles (Driancourt et al. 1998).

The process of ovulation induces the production of reactive oxygen species (ROS) in the ovary after the luteinizing hormone (LH) surge (Brännström et al. 1993). Peri-estrus oxidative stress has been associated with reduced fertility and perturbation of oocytes (Guerin et al. 2001) and embryonic development (Ufer \& Wang 2011 ) in many species. Despite this cytotoxicity, a basal oxidation stress appears necessary for the ovulation process (Van der Hoek et al. 2000) and subsequent embryo development (Orsi \& Leese 2001). Thus, understanding how embryo metabolism regulates the intracellular redox potential is of fundamental importance.
Selenium (Se) is an essential trace element derived from inorganic or organic sources. Organic Se (OSe), the natural form present in feed, is deposited into proteins as selenomethionine (SeMet) following the methionine metabolism (Schrauzer 2003), whereas inorganic Se (MSe), commonly used as a dietary supplement, is readily transformed into selenide and incorporated into some selenoproteins (Windisch 2002). Roughly half of the selenoproteins confer cellular protection against oxidative stress. Both sources of Se can result in Se-dependent glutathione peroxidase (SeGPX) biosynthesis, but the OSe pathway is more complex and responsive to oxidative stress (Gonzalez-Flores et al. 2013). Several reactions of OSe to SeGPX pathway are pyridoxine dependent (Yasumoto et al. 1979). Roy et al. (2011) have shown the importance of pyridoxine for an adequate flow of OSe toward the SeGPX system in response to oxidative stress induced during the peri-estrus period in gilts. 
Although limited, the information on the effects of sources of supplemental Se for sows on developing porcine embryos has shown an increased Se transfer of $60 \%$ to embryos from OSe dams along with an enhanced morphological and physiological development at 30 days of gestation. This was observed in spite of a lack of effect on embryo SeGPX activity (Fortier et al. 2012). The metabolic and physiological mechanisms involved in such responses deserve further investigation. Genomic approaches such as microarray technologies, which have been developed to study gene expression of the whole genome of developing mammalian embryos (Niemann et al. 2007), can be powerful tools for that purpose. Recently, a gene expression microarray specific for porcine embryos has been developed and validated (Tsoi et al. 2012), allowing an efficient analysis of large numbers of different pre-determined transcripts in several samples.

This study aimed to determine the effect of maternal OSe or MSe dietary supplementation combined with pyridoxine on gene expression of the whole genome of porcine expanded blastocysts (PEB) via microarray analysis. In addition, biological processes and some key enzymes/proteins related with embryo Se metabolism, in particular SeGPX, were also investigated.

\section{Material and methods}

\section{Animals and treatments}

Experimental procedures were carried out following the guidelines of the Canadian Council on Animal Care (2009) and were approved by the Institutional Animal Care Committee of the Dairy and Swine Research and Development Centre of Sherbrooke, Québec, Canada (\#400). All animals were cared for and slaughtered according to the recommended code of practice of Agriculture Canada (1993).

Eighteen Yorkshire-Landrace gilts were selected for this study at $96.1 \pm 4.6 \mathrm{~kg}$ BW and aged $135-170$ days and six to seven animals were grouped in pens $(1.5 \times 2.5 \mathrm{~m}$, half-slatted concrete flooring) until the first estrus was detected. For at least 14 days, they were fed a basal breeding/gestation diet ad libitum (Table 1), without Se and pyridoxine supplements but in excess of the recommended NRC (1998) requirements for all other ingredients. Estrus detection was initially performed by introducing a young boar (aged 8-12 months) into the pen once daily (10 min), but was increased to twice daily (10 min each; between 0800 and $0900 \mathrm{~h}$ and from 1600 to $1700 \mathrm{~h}$ ) for the detection of the fifth estrus. From the onset of the first estrus, the gilts were kept in individual stalls $(0.6 \times 2.2 \mathrm{~m}$, half-slatted concrete flooring), their daily feed allowance was limited to $2.8 \mathrm{~kg}$, and on the basis of comparable BW and blood concentrations of Se, they were assigned randomly to one of three experimental diets $(n=6$ per treatment): i) basal diet (Table 1) containing 0.3 and $2.4 \mathrm{mg} / \mathrm{kg}$ of natural Se and pyridoxine, respectively, top-dressed with $50 \mathrm{~g}$ of ground corn without supplemental Se or pyridoxine (CONT); ii) the basal diet top-dressed with $50 \mathrm{~g}$ of ground corn with supplemental Se
Table 1 Composition of the basal diet (as-fed basis) ${ }^{a, b}$.

\begin{tabular}{lc}
\hline Ingredients & Amount $(\%)$ \\
\hline Corn & 52.6 \\
Wheat shorts & 20.0 \\
Distillers dried grain with solubles & 10.0 \\
Canola meal & 9.7 \\
Soybean hulls & 4.0 \\
Limestone & 2.0 \\
Salt & 0.6 \\
Biofos & 0.5 \\
L-lysine *P* & 0.1 \\
Chlorure choline & 0.1 \\
Feed curb & 0.1 \\
Mineral and vitamin premix & 0.3 \\
\hline
\end{tabular}

${ }^{\mathrm{a}}$ The calculated compositions for $\mathrm{ME}, \mathrm{CP}$, lysine, $\mathrm{Ca}$, and $\mathrm{P}$ of the basal diet were $2702 \mathrm{kcal} / \mathrm{kg}, 14.0,0.6,1.0$, and $0.6 \%$ respectively. ${ }^{\mathrm{b}}$ The basal Se and pyridoxine contents of the diet were 0.3 and $1.7 \mathrm{mg} / \mathrm{kg}$ respectively (analytical values determined according to Matte et al. (2001) and Giguère et al. (2005) respectively). ' Provided per kilogram of diet: $\mathrm{Mn}$ as manganous oxide, $40 \mathrm{mg}$; $\mathrm{Zn}$ as zinc oxide, $150 \mathrm{mg}$; Fe as ferrous sulfate, $140 \mathrm{mg}$; $\mathrm{Cu}$ as copper sulfate, $21 \mathrm{mg}$; I as calcium iodate, $2.0 \mathrm{mg}$; vitamin A, $14580 \mathrm{IU}$; vitamin D, $1500 \mathrm{IU}$; vitamin E, $44 \mathrm{IU}$; vitamin K, $2.6 \mathrm{mg}$; thiamine, $2.7 \mathrm{mg}$; riboflavin, $4.9 \mathrm{mg}$; niacin, $31 \mathrm{mg}$; pantothenic acid, $21 \mathrm{mg}$; folic acid, $10 \mathrm{mg}$; biotin, $400 \mu \mathrm{g}$; and vitamin B12, $25 \mu \mathrm{g}$.

and pyridoxine, providing an equivalent of $0.3 \mathrm{mg} / \mathrm{kg}$ of feed of MSe as sodium selenite, and $10 \mathrm{mg} / \mathrm{kg}$ of feed of pyridoxine, as hydro-chloride pyridoxine (P9755, Sigma-Aldrich; $\mathrm{MSeB}_{6} 10$ ); and iii) the basal diet top-dressed with $50 \mathrm{~g}$ of ground corn with supplemental Se and pyridoxine, providing an equivalent of $0.3 \mathrm{mg} / \mathrm{kg}$ of feed of OSe as Se-enriched yeast, and $10 \mathrm{mg} / \mathrm{kg}$ of feed of pyridoxine, as hydro-chloride pyridoxine $\left(\mathrm{OSeB}_{6} 10\right)$. At the fifth estrus, all gilts were inseminated with $85 \mathrm{ml}$ of semen $\left(3 \times 10^{9}\right.$ live sperm cells pooled from the same three Duroc boars) provided by a local Al center (CIPQ, Inc., St-Lambert, QC, Canada). When estrus was detected in the morning, the gilts were inseminated twice, 8 and $24 \mathrm{~h}$ later. When estrus was detected in the afternoon, two inseminations were done 16 and $24 \mathrm{~h}$ later. The gilts were killed 5 days after the first insemination. Average BW was $138.5 \pm 6.3$ and $181.3 \pm 6.3 \mathrm{~kg}$ at the initiation of treatment and at the end of the experiment respectively.

\section{Sampling}

Blood samples were collected into EDTA-containing tubes $(10 \mathrm{ml}$; Becton Dickinson and Co., Rutherford, NJ, USA) by jugular vein venipuncture from all gilts at arrival to the research center, on the day after onset of each estrus, and at slaughter. The blood samples were stored at $-20^{\circ} \mathrm{C}$ for the determination of Se concentrations. Blood plasma and erythrocyte samples were obtained after centrifugation of blood at $1800 \mathrm{~g}$ for 12 min at $4{ }^{\circ} \mathrm{C}$ and stored at $-20^{\circ} \mathrm{C}$ and at $-80{ }^{\circ} \mathrm{C}$ for the determination of pyridoxal-5-phosphate (P-5-P) and SeGPX activity respectively.

At slaughter, the reproductive tract, liver, and kidneys were collected from all gilts (six per treatment). Liver weight and ovulation rate (number of corpora lutea $(\mathrm{CL})$ ) were recorded. Samples of liver and kidney tissue were collected and frozen in liquid nitrogen. 


\section{Embryo (day 5) collection and storage}

Both uterine horns were immediately flushed twice with $20 \mathrm{ml}$ of PBS/BSA $\left(37^{\circ} \mathrm{C}\right)$ and the flushing samples collected into $50 \mathrm{ml}$ Falcon tubes and kept at $37^{\circ} \mathrm{C}$. In laboratory, flushing samples were transferred to a Petri dish $\left(37^{\circ} \mathrm{C}\right)$ and embryos were harvested using a dissection microscope. Each embryo was transferred to another Petri dish $\left(37^{\circ} \mathrm{C}\right)$ previously prepared with microdroplets of $\mathrm{mDPBS} / \mathrm{BSA}$ (modified Dulbecco PBS: PBS solution-added D-glucose, sodium pyruvate, magnesium chloride $\left(\mathrm{MgCl}_{2} \cdot 6 \mathrm{H}_{2} \mathrm{O}\right)$, and calcium chloride $\left.\left(\mathrm{CaCl}_{2} \cdot 2 \mathrm{H}_{2} \mathrm{O}\right)\right)$. The embryos were classified according to their developmental stage as two to four cells, four to eight cells, morula, compact morula, early blastocyst, blastocyst, or expanded blastocyst. The groups of three to six similar stage embryos were transferred to a Petri dish previously containing mDPBS droplets without BSA under mineral oil $\left(37^{\circ} \mathrm{C}\right)$. Then, each group of embryos was transferred to a corresponding microcentrifuge tube with not more than $20 \mu \mathrm{l}$ of mDPBS without BSA and frozen immediately in dry ice and kept at $-80{ }^{\circ} \mathrm{C}$ until analysis. The samples of the first flushing of each uterine horn were frozen at $-20^{\circ} \mathrm{C}$ for the determination of Se and P-5-P concentrations. All gilts were pregnant and available for embryo harvesting, but as the microarray used was specific for PEB, litters had to be selected based on the developmental stage of embryos for suitable biomolecular analysis. The pools of three to six expanded blastocysts from the same gilt could be finally constituted from 11 gilts. They were distributed as follow: 4, 4, and 3 in CONT, $\mathrm{MSeB}_{6} 10$, and $\mathrm{OSeB}_{6} 10$ fed gilts respectively.

\section{Laboratory analysis}

Measurements of Se were done using a fluorimetric method adapted by Giguère et al. (2005) from the technique of Sheehan \& Gao (1990) and P-5-P was determined using a fluorimetric method adapted by Matte et al. (1997) from the technique of Srivastava \& Beutler (1973). SeGPX activity was determined in blood plasma by the spectrophotometric method described by Gunzler \& Flohe (1985). The activities are reported as milliunits $(\mathrm{mU})$ per $\mathrm{mg}$ of protein with $1 \mathrm{unit}=1 \mu \mathrm{mol} \mathrm{NADPH}$ oxidized/min.

\section{Total RNA extraction}

The ArcturusW PicoPureW RNA Isolation Kit (Applied Biosystems) was used for RNA extraction on each individual sample tube containing three to six embryos. High-quality total RNA was obtained from each sample after DNase treatment using the RNase-Free DNase Kit according to the protocol from Qiagen. Total RNA quality was evaluated with an Agilent 2100 Bioanalyzer using the RNA 6000 Pico Kit (Agilent Technologies, Mississauga, ON, Canada). RNA integrity number (RIN) index was used as a numerical assessment of the integrity of RNA and ranged between 7.8 and 9.7. RNA amplification (RiboAmp HSPlus Kit; Applied Biosystems) was used to amplify the low quantities of total RNA isolated from the samples, with only 0.6-3.6 ng of total RNA available for amplification. Antisense RNA (aRNA) was generated from each sample and the quality of each amplified aRNA sample was checked using an RNA 6000 Nano Kit (Agilent Technologies). For all good quality samples, Nanodrop ND-1000 (NanoDrop Technologies, Wilmington, DE, USA) was used to determine the aRNA concentration.

\section{Microarray procedure and analysis}

The porcine embryo-specific microarray platform generated by Agilent (Tsoi et al. 2012) was used in this study. The platform information has been previously deposited and is available from NCBI the Gene Expression Omnibus (GEO) repository with the GEO ID: GPL14925.

A two-color microarray with a dye-swap replicate was performed for the $\mathrm{MSeB}_{6} 10$ vs CONT and $\mathrm{OSeB}_{6} 10$ vs CONT comparison to identify all the differentially expressed (DE) genes. Four biological replicates for the $\mathrm{MSeB}_{6} 10$ vs CONT and three biological and one technical replicate for the $\mathrm{OSeB}_{6} 10 \mathrm{vs}$ CONT comparisons were used in the experimental design. In addition, a reference design (Konig et al. 2004) was chosen using the same CONT group used in the previous comparisons as a reference for a reliable indirect comparison of gene expression for $\mathrm{MSeB}_{6} 10$ vs $\mathrm{OSeB}_{6} 10$.

All the details regarding probe labeling, hybridization, and washing were previously described by Tsoi et al. (2012) and Zhou et al. (2014). In general, concentrations of the labeled probes and their degrees of labelling (DOL) were determined by Nanodrop ND-1000 with an average of $125.08 \mathrm{ng} / \mathrm{ml}$ and 1.2 Cy3 molecules into the anti-sense RNA respectively.

Immediately after the final washing and drying procedures, the arrays were scanned at $5 \mu \mathrm{m}$ resolution with an Axon 4200AL scanner (635 nm for Cy5 and at $532 \mathrm{~nm}$ for Cy3) using the autoscan feature from the default setting, and the images were analyzed with the Gene Pix Pro 6.0 Software (Molecular Device, Sunnyvale, CA, USA). The analyzed images were manually edited for any spots with hybridization artefacts and flagged for exclusion. The data from spot intensity, background subtraction, and normalization were saved in the GenePix Results (GPR) format for further data analysis.

The updated annotation with all the DE genes (adjusted $P$ value $\leq 0.05$ and $\log 2$ fold change $\geq 1.7$ or $\leq-1.7$ ), matching with the original probe ID and sequences, was performed first through NCBI Basic Local Alignment Search Tool (BLAST) with the porcine RefSeq RNA (51 160 sequences) and ESTs (1 676424 sequences) database. Similar search was performed by using the pig accession numbers with the human RefSeq RNA (91 603 sequences) to obtain the gene symbols (GSs) (Supplementary Table 1, see section on supplementary data given at the end of this article) for further Gene Ontology Enrichment Analysis.

\section{Bioinformatics tools and analysis}

The Venny interactive tool to associate DE gene lists with Venn diagram (http://bioinfogp.cnb.csic.es/tools/venny/) was used to identify unique GSs from each comparison. The list of unique human GSs obtained from Venny analysis was further uploaded to the GORILLA Classification System (http://cbl-gorilla.cs. technion.ac.il/) to identify biological processes most related to each comparison (Eden et al. 2009). 
A list of 15760 unique GSs from re-annotated EMPV1 was used as background when using two unranked lists of genes (target and background lists) as a running mode during the search. The differences were considered significant at false discovery rate $(\mathrm{FDR}) q$-value $<0.05$.

\section{Quantitative real-time RT-PCR and analysis}

A two-step quantitative real-time RT-PCR (RT-qPCR) was performed on the same aRNA samples used for the microarray experiment. Two micrograms of aRNA was obtained from each individual sample with three biological samples from each group (CONT, $n=3$ and $\mathrm{OSeB}_{6} 10, n=3$ ) to synthesise cDNA using the SuperScript VILO cDNA Synthesis Kit (Life Technologies, Inc.). Three technical replicates were performed for each biological sample using the KAPASYBFAST qPCR Kit (Kapa Biosystems, Inc., Wilmington, MA, USA) with diluted CDNA as a template from a range of 100, 50, 25, 5, 1, and $0.25 \mathrm{ng}$. The RT-qPCR conditions strictly followed the manual provided by the kit manufacturer. A RT without reverse transcriptase (negative control) was also performed together from the same plate with the ABI $7900 \mathrm{HT}$ PCR system. Melting curves and primer efficiencies were obtained from SDS2.3 Software (Applied Biosystems) installed in the system by performing auto-setting for threshold cycle $(\mathrm{Ct})$ and baseline calculation.

Two control genes, hypoxanthine phosphoribosyltransferase 1 (HPRT1) and peptidylprolyl isomerase A (PPIA), were selected according to $\mathrm{RT}^{2}$ ProfilerPCR Array Pig Housekeeping Genes (Qiagen, Inc.). Of the two identified genes, PPIA was selected as the reference gene due to the lower stability measurement value (Vandesompele et al. 2002) compared with HPRT1. Based on the microarray data, four DE genes related with ROS disposal systems: coenzyme Q6 monooxygenase (COQ6), glutaredoxin-3 (GLRX3), peroxiredoxin-4 (PRDX4), and thioredoxin (TXN) and two genes involved in $\mathrm{B}_{6}$ (pyridoxine kinase $(P D X K))$ or Se metabolism (Sep (O-phosphoserine) tRNA:selenocysteine tRNA synthase (SEPSECS)) were chosen for RT-qPCR validation. The mRNA expressions of these genes were normalized with PPIA. The factor of upregulation is equal to the given value in the Randomization
Data Output Box and the downregulation factor is illustrated as a reciprocal value (Pfaffl et al. 2002).

High RT-qPCR efficiencies (99.00-99.99\%) and a single peak after melting curve analysis for all housekeeping genes and genes of interest were confirmed. The sequence information of the primers is given in Table 2. The total expression ratio of the six genes of interest was tested for significance between CONT and $\mathrm{OSeB}_{6} 10$.

\section{Statistical analysis}

Data were analyzed using the SAS procedure for mixed models (SAS Inst., Inc., Cary, NC, USA) according to a randomized arrangement of treatments in blocks, with the three dietary treatments as the main independent variables. The model was as follows: $Y i j=\mu+F j+e i j$, where $Y i j=d e p e n d e n t$ variable, $\mathrm{Fj}=$ dietary treatments, and eij=residual error. The gilt was considered to be the experimental unit. The residual error term was used to test the treatment effects. For the analysis of blood Se, blood plasma SeGPX activity and blood erythrocyte $\mathrm{P}-5-\mathrm{P}$ concentration sampling times were added to the model as a second factor and were analyzed using repeated option of the MIXED procedure of SAS. The sampling times were considered during the whole experiment (six samples, from the first estrus to slaughter). A priori comparisons were done between CONT and MSe + OSe groups (SUPPL) and also between MSe and OSe groups (Se source). The differences were considered significant at $P \leq 0.05$ and tendencies at $0.05<P \leq 0.10$, and all results are expressed as adjusted means \pm S.E.M.

Microarray data statistical analysis was performed using FlexArray (version 1.6.2, http://genomequebec.mcgill.ca/FlexArray), as described previously by Zhou et al. (2014) using a default setting of $P$ value $=0.05$ and fold-change threshold $=2.0$ respectively. In general, after executing the correct background algorithm using the simple subtraction method, further normalizations within (loess) and between arrays were performed. The normalized log2 ratio of all three comparisons was submitted to NCBI GEO Database (GSE51249). Further statistical analysis using the 'limma' package (Smyth 2005), the Benjamini and Hochberg FDR (BH-FDR), and the multiple comparison

Table 2 Primer sequences used for RT-qPCR amplifications of reference gene and genes encoding antioxidant enzymes in porcine expanded blastocysts.

\begin{tabular}{|c|c|c|c|c|}
\hline Genes & Primer sequences $\left(5^{\prime} \rightarrow 3^{\prime}\right)$ & GenBank accession no. & Product size $(b p)$ & $\begin{array}{l}\text { Amplification } \\
\text { efficiency }(\%)\end{array}$ \\
\hline HPRT1 & $\begin{array}{l}\text { (F) CAGTGACAGCACTTAGAGGTATT } \\
\text { (R) GACAACAACTCACCGGAAATAATC }\end{array}$ & NM_001032376.2 & 126 & 99.6 \\
\hline PPIA & $\begin{array}{l}\text { (F) GGTGACTTCACACGCCATAA } \\
\text { (R) GACCCGTATGCTTCAGGATAAA }\end{array}$ & NM_214353.1 & 91 & 99.1 \\
\hline PRDX4 & $\begin{array}{l}\text { (F) GTGGCCAAGAGAAGAGCTATAA } \\
\text { (R) GCATCTTGACCTGAG GAAGTAT }\end{array}$ & XM_005673496.1 & 94 & 99.8 \\
\hline COQ6 & $\begin{array}{l}\text { (F) CCAGCCCTTGGGTTCATATT } \\
\text { (R) GACTGGTCATAGTTCCAGCTAAC }\end{array}$ & XM_001929106.3 & 136 & 99.3 \\
\hline GLRX3 & $\begin{array}{l}\text { (F) GGAAACAAACAGGAAGCCAAG } \\
\text { (R) GTATGTCGAACGTCTCGTAGTC }\end{array}$ & XM_005671576.1 & 91 & 99.9 \\
\hline$P D X K$ & $\begin{array}{l}\text { (F) CAGAGCAAGAGGGACATTGAG } \\
\text { (R) CACAAGGACGGAAACAGACA }\end{array}$ & NM_213943.1 & 113 & 99.1 \\
\hline SEPSEC & $\begin{array}{l}\text { (F) CAAGGTATCTGGAGCTGACAAT } \\
\text { (R) ACCCTTCACATGTCATCAAGAA }\end{array}$ & XM_003356876.2 & 124 & 99.0 \\
\hline$T X N$ & (F) CTCGTAGTGGTCGATTTCTCAG & NM_214313.2 & 100 & 99.9 \\
\hline
\end{tabular}




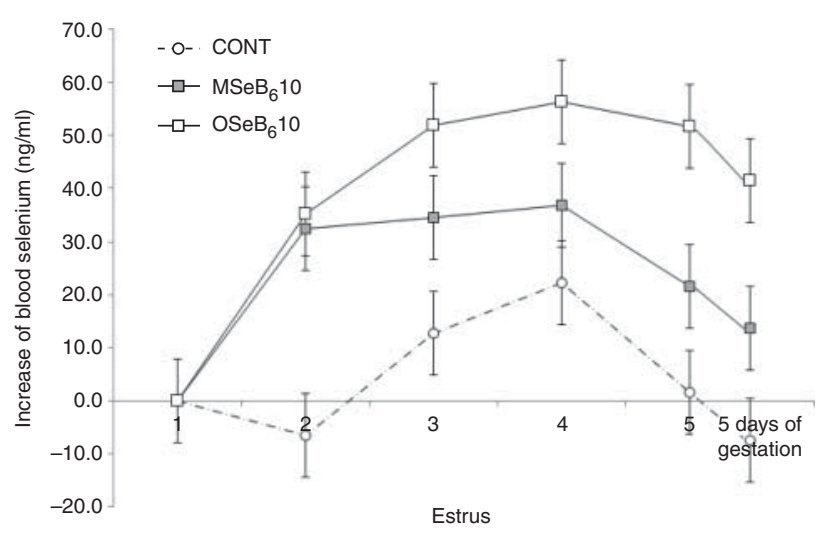

Figure 1 Increase in blood selenium concentration $(\mathrm{ng} / \mathrm{ml})$ of gilts on each estrus, presented as LS means \pm S.E.M. CONT, basal diet containing 0.3 and $2.4 \mathrm{mg} / \mathrm{kg}$ of natural Se and pyridoxine respectively; $\mathrm{MSeB}_{6} 10$, basal diet supplemented with $0.3 \mathrm{mg} / \mathrm{kg}$ of sodium selenite (SigmaAldrich) and $10 \mathrm{mg} / \mathrm{kg}$ of hydro-chloride pyridoxine (P9755, SigmaAldrich); and $\mathrm{OSeB}_{6} 10$, basal diet supplemented with $0.3 \mathrm{mg} / \mathrm{kg}$ of Se-enriched yeast (Alltech, Inc., Nicholasville, KY, USA) and $10 \mathrm{mg} / \mathrm{kg}$ of hydro-chloride pyridoxine (P9755, Sigma-Aldrich).

correction condition (Benjamini \& Hochberg 1995) along with dye effect correction was performed to identify DE genes.

For RT-qPCR analysis, the Relative Expression Software Tool 2009 (REST; http://rest.gene-quantification.info/) was used to implement a randomized test (Pfaffl et al. 2002) and to assess statistical significance of the up- or down-regulation of the target genes after normalization to the reference gene. Statistical analyses were considered significant at $P \leq 0.05$.

\section{Results}

\section{Blood measurements}

Whole blood Se concentrations expressed as increases relative to pre-treatment values at estrus 1 were lower in CONT than in supplemented gilts (CONT vs SUPPL, $P<0.01$ ), and greater in OSe gilts than in MSe gilts (Se source, $P<0.05$; Fig. 1). Globally, from the first estrus to 5 days of gestation, whole blood Se decreased by $2.7 \%$ for CONT and increased by 4.9 and $15.4 \%$ for $\mathrm{MSeB}_{6} 10$ and $\mathrm{OSeB}_{6} 10$ respectively (treatment $\times$ time interaction, $P<0.05)$. During the complete experimental period, lower concentrations of P-5-P in blood erythrocytes were found in CONT than in supplemented gilts (CONT vs SUPPL, $P<0.05$; Fig. 2).

SeGPX activity in blood plasma tended to increase during the experimental period (time effect, $P<0.06)$ but no treatment effect was found $(P=0.57)$. Average values were $39.36 \pm 2.29,43.84 \pm 4.50$, and $42.54 \pm 2.33 \mathrm{mU} / \mathrm{g}$ protein at first and fifth estrus, and at slaughter respectively.

\section{Physiological and reproduction measurements at slaughter}

There was no treatment effects (Table 3 ) on liver weight $(P \geq 0.17)$, liver Se concentration $(P \geq 0.21)$, total liver
Se $(P \geq 0.24)$, kidney Se concentration $(P \geq 0.24)$, ovulation rate $(P \geq 0.24)$, embryos recovery rate $(P \geq 0.19)$, viable embryos $(P \geq 0.11)$, degenerated embryos $(P \geq 0.14)$, early-stage embryos (from two to four cell to compact morula) $(P \geq 0.81)$, advanced-stage embryos (from early blastocyst to expanded blastocyst) $(P \geq 0.18)$, and total number of embryos $(P \geq 0.25)$. In the uterine flushes, $P-5-P$ concentrations were similar among treatments $(P \geq 0.13)$, but Se was not detectable $(<10 \mathrm{ng} / \mathrm{ml})$.

\section{Differential gene expression profile}

The Venn diagram including the three comparisons is presented in Fig. 3. The comparisons $\mathrm{MSeB}_{6} 10$ vs CONT and $\mathrm{OSeB}_{6} 10$ vs CONT correspond to the synergy of OSe or MSe with $B_{6}$, whereas the $\mathrm{OSeB}_{6} 10$ vs $\mathrm{MSeB}_{6} 10$ comparison excludes the $B_{6}$ influence and represents a specific effect of OSe vs MSe.

The direct comparison $\mathrm{MSeB}_{6} 10$ vs CONT showed a total of ten DE genes in the PEB, with nine upregulated $(90.0 \%)$, and one downregulated gene $(10.0 \%)$ in $\mathrm{MSeB}_{6} 10$. Only two genes had an absolute $(-$ or +$)$ fold change $\geq 2$. All those genes are given in Table 4. For $\mathrm{OSeB}_{6} 10$ vs CONT comparison, a total of 247 genes were DE, with 185 upregulated (75.3\%) and 62 downregulated genes $(24.7 \%)$ in $\mathrm{OSeB}_{6} 10$. Among these genes, 119 had an absolute fold change $\geq 2$, and eight of them were $\geq 3$. The ten most up- and down-regulated genes are listed in Table 5. Regarding the reference design comparison $\left(\mathrm{OSeB}_{6} 10\right.$ vs $\left.\mathrm{MSeB}_{6} 10\right)$, there were 96 DE genes. $\mathrm{OSeB}_{6} 10$ had 60 upregulated (62.5\%) and

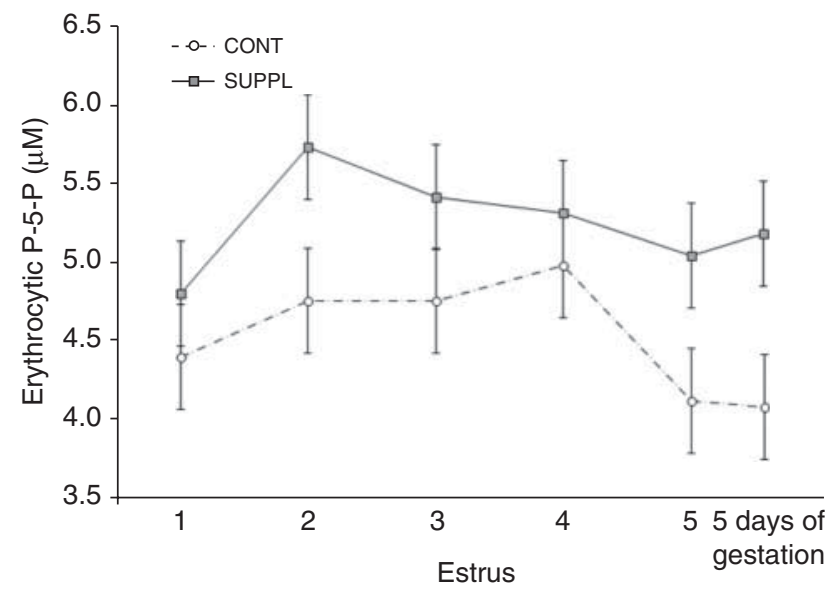

Figure 2 Blood erythrocytic P-5-P concentration $(\mu \mathrm{M})$ of gilts for each estrus, presented as LS means \pm S.E.M. CONT, basal diet containing 0.3 and $2.4 \mathrm{mg} / \mathrm{kg}$ of natural Se and pyridoxine respectively; $\mathrm{MSeB}_{6} 10$, basal diet supplemented with $0.3 \mathrm{mg} / \mathrm{kg}$ of sodium selenite (Sigma-Aldrich) and $10 \mathrm{mg} / \mathrm{kg}$ of hydro-chloride pyridoxine (P9755, Sigma-Aldrich); and $\mathrm{OSeB}_{6} 10$, basal diet supplemented with $0.3 \mathrm{mg} / \mathrm{kg}$ of Se-enriched yeast (Alltech, Inc.) and $10 \mathrm{mg} / \mathrm{kg}$ of hydro-chloride pyridoxine (P9755, Sigma-Aldrich). SUPPL, average values of $\mathrm{MSeB}_{6} 10+\mathrm{OSeB}_{6} 10$. 
Table 3 Physiological and reproduction measurements at slaughter.

\begin{tabular}{|c|c|c|c|c|c|c|}
\hline \multirow[b]{2}{*}{ Measurements } & \multirow[b]{2}{*}{ CONT } & \multirow[b]{2}{*}{$\mathrm{MSeB}_{\mathbf{6}} \mathbf{1 0}$} & \multirow[b]{2}{*}{$\mathrm{OSeB}_{6} 10$} & \multirow[b]{2}{*}{ S.E.M. } & \multicolumn{2}{|c|}{ A priori comparisons } \\
\hline & & & & & CONT vs SUPPL & $\mathrm{MSeB}_{6} 10$ vs $\mathrm{OSeB}_{6} 10$ \\
\hline $\begin{array}{l}\text { Uterine flush selenium } \\
\text { concentration }(\mathrm{ng} / \mathrm{ml})\end{array}$ & - & - & - & - & - & - \\
\hline $\begin{array}{l}\text { Uterine flush } \\
\text { pyridoxal-5-phosphate }(\mu \mathrm{M})\end{array}$ & 0.33 & 0.50 & 0.17 & 0.16 & 0.99 & 0.13 \\
\hline Liver weight $(\mathrm{kg})$ & 1.93 & 1.78 & 1.91 & 60.40 & 0.26 & 0.17 \\
\hline Liver selenium concentration $(\mu \mathrm{g} / \mathrm{g})$ & 1.07 & 1.14 & 1.21 & 0.07 & 0.21 & 0.47 \\
\hline $\begin{array}{l}\text { Total liver selenium } \\
\text { concentration (mg) }\end{array}$ & 2.08 & 2.04 & 2.32 & 0.02 & 0.60 & 0.24 \\
\hline Kidney selenium concentration $(\mu \mathrm{g} / \mathrm{g})$ & 3.22 & 3.40 & 3.63 & 0.02 & 0.24 & 0.44 \\
\hline $\begin{array}{l}\text { Ovulation rate/number of } \\
\text { corpora lutea }(n)\end{array}$ & 18.83 & 18.83 & 19.67 & 1.16 & 0.86 & 0.24 \\
\hline Embryo recovery rate (\%) & 76.92 & 85.61 & 92.74 & 7.17 & 0.19 & 0.50 \\
\hline Viable embryos $(n)$ & 14.17 & 13.50 & 18.17 & 1.88 & 0.48 & 0.11 \\
\hline Degenerated embryos $(n)$ & 0.50 & 2.00 & 0.00 & 0.96 & 0.65 & 0.14 \\
\hline Early-stage embryos $(n)$ & 3.33 & 4.30 & 3.67 & 2.15 & 0.81 & 0.83 \\
\hline Advanced-stage embryos $(n)$ & 10.83 & 9.17 & 14.50 & 2.62 & 0.76 & 0.18 \\
\hline Total embryos $(n)$ & 14.67 & 15.50 & 18.17 & 1.60 & 0.28 & 0.25 \\
\hline
\end{tabular}

CONT, basal diet containing 0.3 and $1.7 \mathrm{mg} / \mathrm{kg}$ of natural Se and pyridoxine respectively; $\mathrm{MSeB}_{6} 10$, basal diet supplemented with $0.3 \mathrm{mg} / \mathrm{kg}$ of sodium selenite (Sigma-Aldrich) and $10 \mathrm{mg} / \mathrm{kg}$ of hydro-chloride pyridoxine (P9755, Sigma-Aldrich); and OSeB 610 , basal diet supplemented with $0.3 \mathrm{mg} / \mathrm{kg}$ of Se-enriched yeast (Alltech, Inc.) and $10 \mathrm{mg} / \mathrm{kg}$ of hydro-chloride pyridoxine (P9755, Sigma-Aldrich). SUPPL, average values of $\mathrm{MSeB}_{6} 10+\mathrm{OSeB}_{6} 10$.

36 downregulated genes $(37.5 \%)$, compared with $\mathrm{MSeB}_{6} 10$. A total of 44 genes had an absolute fold change $\geq 2$, and four of them were $\geq 3$. The ten most up- and down-regulated genes are listed in Table 6. The complete list of genes related with each comparison are shown in Supplementary Table 2, see section on supplementary data given at the end of this article.

\section{Biological process analysis of the unique DE genes}

For the analysis of biological processes related with $\mathrm{DE}$ genes in PEB after maternal supplementations, the common unique GSs between comparisons were excluded and only the exclusive unique GSs of each comparison were selected (6, 173, and 25 exclusive genes for $\mathrm{MSeB}_{6} 10$ vs CONT, $\mathrm{OSeB}_{6} 10$ vs CONT, and $\mathrm{OSeB}_{6} 10$ vs $\mathrm{MSeB}_{6} 10$ comparisons respectively) and uploaded to GORILLA.

Regarding the $\mathrm{OSeB}_{6} 10$ vs CONT comparison, four distinct biological processes (gene expression, translation, regulation of translation, and mitotic cell cycle) were stimulated (FDR $q$-value $<0.05$ ). When comparing $\mathrm{MSeB}_{6} 10$ vs CONT and $\mathrm{OSeB}_{6} 10$ vs $\mathrm{MSeB}_{6} 10$, no biological process was selectively stimulated by $\mathrm{MSeB}_{6} 10$ and $\mathrm{OSeB}_{6} 10$ respectively (FDR $q$-value $>0.05$ ).

\section{Expression of genes involved in glutathione and SeGPX metabolism}

Although not influenced by treatments, several genes related with the methionine cycle and transsulfuration pathway were identified (Table 7). Also, the genes responsible for the metabolism between forms of pyridoxine (dietary $\mathrm{HCl}$-pyridoxine vs metabolic $\mathrm{P}-5-\mathrm{P}$ ) were identified: pyridoxamine $5^{\prime}$-phosphate oxidase $(P N P O$, fold change ranging from -0.2 to 0.1 and average $P=0.41$ ) and $P D X K$ (identified by RT-qPCR).

\section{Other ROS disposal-related genes}

Treatment effects on the expression of genes related with ROS balance included upregulation of GLRX3 (1.7 fold change, $P<0.01)$, PRDX4 (1.7 fold change, $P<0.01$ ),

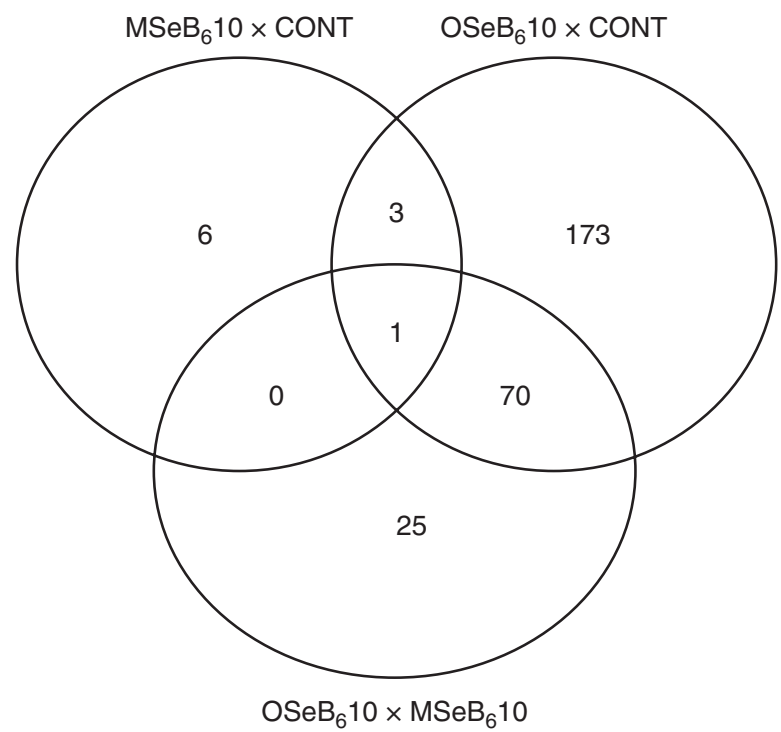

Figure 3 Venn diagram summarizing the microarray analysis of $\mathrm{MSeB}_{6} 10$ vs CONT, $\mathrm{OSeB}_{6} 10$ vs CONT, and $\mathrm{OSeB}_{6} 10$ vs $\mathrm{MSeB}_{6} 10$ comparisons. 
Table 4 Differentially expressed genes in the expanded blastocysts of gilts supplemented with $\mathrm{MSeB}_{6} 10$ compared with CONT group.

\begin{tabular}{llcl}
\hline Genes & Description & Fold change & P value \\
\hline Up- and down-regulated genes & & 2.1 \\
PCBP2 & Poly(rC)-binding protein 2, transcript variant X6 & 2.0 & $1.73 \times 10^{-2}$ \\
DALRD3 & DALR anticodon-binding domain containing 3 & 1.9 & $3.43 \times 10^{-2}$ \\
CCT3 & Chaperonin-containing TCP1, subunit 3 (gamma) & 1.9 & $1.58 \times 10^{-2}$ \\
PAAF1 & Proteasomal ATPase-associated factor 1, transcript & & $1.62 \times 10^{-2}$ \\
& variant X1 & 1.8 & $2.97 \times 10^{-2}$ \\
EIF4G2 & Eukaryotic translation initiation factor 4 gamma 2 & 1.7 & $2.81 \times 10^{-2}$ \\
MCL1 & Myeloid cell leukemia sequence 1 (BCL2-related) & 1.7 & $3.34 \times 10^{-2}$ \\
TUBA1A & Tubulin, alpha 1a & 1.7 & $2.49 \times 10^{-2}$ \\
HSD17B14 & Hydroxysteroid (17-beta) dehydrogenase 14 & 1.7 & $4.76 \times 10^{-2}$ \\
TMEM129 & Transmembrane protein 129, transcript variant 1 & -1.9 & $8.79 \times 10^{-3}$ \\
HAAO & 3-Hydroxyanthranilate 3,4-dioxygenase & & \\
\hline
\end{tabular}

and COQ6 (1.7 fold change, $P<0.01)$ in the $\mathrm{OSeB}_{6} 10$ vs CONT comparison, and downregulation of $T X N$ (fold change ranging from -2.4 to $-1.9, P<0.01)$ and microsomal glutathione transferase 2 (MGST2; fold change ranging from -2.6 to -2.0 , and $P<0.05)$ in the $\mathrm{OSeB}_{6} 10$ vs CONT and $\mathrm{OSeB}_{6} 10$ vs $\mathrm{MSeB}_{6} 10$ comparisons. Although not Se-dependent, it is noteworthy to mention that major antioxidant enzymes such as superoxide dismutases and catalase were not influenced by treatments.

\section{Validation of microarray data by RT-qPCR}

RT-qPCR confirmed the previous findings for COQ6, $G L R X 3, P R D X 4$, and $T X N$, with expression trends similar to the microarray study. In contrast, RT-qPCR analysis indicated no difference in relative $P D X K$ expression among treatments $(P=0.38)$ and that SEPSECS was upregulated in the $\mathrm{OSeB}_{6} 10$ group compared with CONT $(P<0.01)$ (Fig. 4).

\section{Discussion}

Blood Se concentrations slightly decreased from the first estrus until 5 days of gestation in CONT gilts fed the basal diet containing a natural level of $0.3 \mathrm{mg} / \mathrm{kg}$ of feed of Se. Such response occurred despite the fact that the present basal dietary Se level was largely higher than the basal level found in cereals grown in Se-deficient soils (Mahan et al. 2005) and also higher than the NRC (1998, 2012) recommendations of $0.15 \mathrm{mg} / \mathrm{kg}$. The Se source effect on whole blood Se concentration of gilts is consistent with previous reports (Schrauzer 2000, Svoboda et al. 2008, Fortier et al. 2012). The absorbed MSe is converted into functional selenoproteins containing selenocysteine (Sec), with slight storage in organs (Windisch 2002). The organic source is either metabolized to reactive forms of Se or stored as SeMet during protein synthesis (Schrauzer 2003).

The enrichment analysis indicated a marked difference of DE genes among $\mathrm{MSeB}_{6} 10$ vs CONT,

Table 5 Top ten up- and down-regulated genes in the expanded blastocysts of gilts supplemented with OSeB 610 compared with CONT group.

\begin{tabular}{|c|c|c|c|}
\hline Genes & Description & Fold change & $P$ value \\
\hline \multicolumn{4}{|c|}{ Upregulated genes } \\
\hline ETNPPL & Ethanolamine-phosphate phospho-lyase & 3.9 & $2.13 \times 10^{-5}$ \\
\hline AK4 & Adenylate kinase 3 -like 1 & 3.1 & $1.62 \times 10^{-4}$ \\
\hline EEF1A2 & Eukaryotic translation elongation factor 1 alpha 2 & 3.0 & $7.57 \times 10^{-6}$ \\
\hline$C D V 3$ & Protein CDV3 homolog (LOC100627162) & 3.0 & $1.24 \times 10^{-5}$ \\
\hline EEF1A2 & Eukaryotic translation elongation factor 1 alpha 2 & 2.9 & $1.01 \times 10^{-4}$ \\
\hline IL6 & Interleukin 6 (interferon, beta 2) & 2.9 & $9.14 \times 10^{-4}$ \\
\hline HENMT1 & Small RNA 2'-O-methyltransferase-like (LOC100152743) & 2.9 & $1.48 \times 10^{-4}$ \\
\hline EEF1A2 & Eukaryotic translation elongation factor 1 alpha 2 & 2.8 & $2.91 \times 10^{-6}$ \\
\hline ST3GAL5 & $\begin{array}{l}\text { Lactosylceramide alpha-2,3-sialyltransferase-like } \\
\text { (LOC100522988) }\end{array}$ & 2.8 & $3.05 \times 10^{-5}$ \\
\hline ATP6VOD2 & ATPase, $\mathrm{H}+$ transporting, lysosomal, $\mathrm{V} 0$ subunit $\mathrm{d} 2$ & 2.7 & $1.35 \times 10^{-5}$ \\
\hline \multicolumn{4}{|c|}{ Downregulated genes } \\
\hline CHAC1 & ChaC, cation transport regulator homolog 1 & -5.0 & $2.38 \times 10^{-3}$ \\
\hline STC2 & Stanniocalcin 2 & -3.6 & $5.31 \times 10^{-4}$ \\
\hline MT1L & Metallothionein-1C-like (LOC100739663) & -3.0 & $3.18 \times 10^{-5}$ \\
\hline$N L N$ & Neurolysin (metallopeptidase M3 family) & -3.0 & $4.16 \times 10^{-6}$ \\
\hline ASNS & Asparagine synthetase (glutamine-hydrolyzing) & -2.9 & $3.24 \times 10^{-6}$ \\
\hline$R G N$ & Regucalcin-like (LOC100523295) & -2.9 & $2.32 \times 10^{-4}$ \\
\hline CYP51A1 & Cytochrome P450, family 51, subfamily A, polypeptide 1 & -2.8 & $2.87 \times 10^{-6}$ \\
\hline MGST2 & Microsomal glutathione $S$-transferase 2 & -2.6 & $2.21 \times 10^{-5}$ \\
\hline AIF1 & Allograft inflammatory factor 1 & -2.6 & $1.36 \times 10^{-3}$ \\
\hline MGST2 & Microsomal glutathione $S$-transferase 2 & -2.5 & $4.26 \times 10^{-5}$ \\
\hline
\end{tabular}


Table 6 Top ten up- and down-regulated genes in the expanded blastocysts of gilts supplemented with $\mathrm{OSeB}_{6} 10$ compared with MSeB 610 group.

\begin{tabular}{|c|c|c|c|}
\hline Genes & Description & Fold change & $P$ value \\
\hline \multicolumn{4}{|c|}{ Upregulated $\mathrm{OSeB}_{6} 10$ genes } \\
\hline ETNPPL & Ethanolamine-phosphate phospho-lyase & 3.4 & $2.18 \times 10^{-3}$ \\
\hline$A K 4$ & Adenylate kinase 3 -like 1 & 3.0 & $2.01 \times 10^{-3}$ \\
\hline IL6 & Interleukin 6 (interferon, beta 2) & 2.8 & $2.21 \times 10^{-3}$ \\
\hline ATP6V0D2 & ATPase, $\mathrm{H}+$ transporting, lysosomal, V0 subunit d2 & 2.7 & $1.50 \times 10^{-3}$ \\
\hline MYL6 & Myosin, light chain 6 , alkali, smooth muscle and non-muscle & 2.5 & $4.82 \times 10^{-2}$ \\
\hline$R \cup V B L 2$ & RuvB-like 2 , transcript variant $\mathrm{X} 3$ & 2.4 & $2.10 \times 10^{-2}$ \\
\hline EEF1A2 & Eukaryotic translation elongation factor 1 alpha 2 & 2.4 & $1.46 \times 10^{-2}$ \\
\hline ST3GAL5 & Lactosylceramide alpha-2,3-sialyltransferase-like (LOC100522988) & 2.4 & $5.25 \times 10^{-3}$ \\
\hline KPNA3 & Karyopherin alpha 3 & 2.3 & $1.13 \times 10^{-3}$ \\
\hline EEF1A2 & Eukaryotic translation elongation factor 1 alpha 2 & 2.2 & $1.16 \times 10^{-2}$ \\
\hline \multicolumn{4}{|c|}{ Downregulated $\mathrm{OSeB}_{6} 10$ genes } \\
\hline CHAC1 & ChaC, cation transport regulator homolog 1 & -4.0 & $6.72 \times 10^{-3}$ \\
\hline STC2 & Stanniocalcin 2 & -3.4 & $8.99 \times 10^{-3}$ \\
\hline ASNS & Asparagine synthetase (glutamine-hydrolyzing) & -2.9 & $8.15 \times 10^{-3}$ \\
\hline$R G N$ & Regucalcin transcript variant 1 & -2.8 & $1.74 \times 10^{-2}$ \\
\hline$N L N$ & Neurolysin & -2.4 & $1.44 \times 10^{-3}$ \\
\hline SLC7A9 & Solute carrier family 7 (amino acid transporter light chain), member 9 & -2.4 & $4.36 \times 10^{-2}$ \\
\hline MT1L & Metallothionein $1 \mathrm{~L}$ & -2.3 & $9.89 \times 10^{-3}$ \\
\hline IDI1 & Isopentenyl-diphosphate delta isomerase 1 & -2.3 & $1.20 \times 10^{-3}$ \\
\hline$R G N$ & Regucalcin, transcript variant 2 & -2.2 & $4.30 \times 10^{-2}$ \\
\hline MINOS1 & Mitochondrial inner membrane organizing system 1 & -2.2 & $1.39 \times 10^{-3}$ \\
\hline
\end{tabular}

$\mathrm{OSeB}_{6} 10$ vs CONT, and $\mathrm{OSeB}_{6} 10$ vs $\mathrm{MSeB}_{6} 10$ comparisons. Globally, $\mathrm{OSeB}_{6} 10$ supplementation to gilts affected PEB transcriptome more drastically than $\mathrm{MSeB}_{6} 10$, suggesting an additive effect of $\mathrm{B}_{6}$ with OSe but not with MSe. Such responses might be related to the fact that the organic source of Se can become an integral part of many proteins, not only antioxidant enzymes, whereas MSe is largely directed toward antioxidant metabolism, as mentioned above. Moreover, the complexity of the metabolic interaction between $\mathrm{B}_{6}$ and OSe compared with MSe (Le Floc'h et al. 2012) could also explain the higher number of genes affected.

Although it cannot be ruled out that feeding a chemical compound or yeast extracts as supplements may have conferred differences in genes expression, metabolic indicators such as circulating Se showed that the Se status was clearly altered and modulated by sources and levels of dietary Se. It appears unlikely that such major systemic changes on the metabolism of sows were due to the yeast fraction of dietary organic Se. The marked DE differences (especially from OSeB ${ }_{6} 10$ ) would require such type of systemic route for metabolism because they were observed on organisms (expanded blastocysts) that are self-regulated and genetically dissimilar (half allogenic) from those (dams) receiving directly the treatments. In terms of Se transfer from dams to embryos, whatever the treatment, Se was undetectable in the uterine flushing. Therefore, although the pre-implantation embryo is nourished by the uterine fluids, it appears that this route of Se transfer is negligible for embryonic metabolism. However, before conception, the Se content of pre-ovulatory oocytes might have been influenced by the systemic effect of different blood Se concentrations, considering that the follicular fluid in which the oocyte matures is a product of the transfer of blood constituents (Fortune 1994). In such way, more Se could have been available to embryos obtained from $\mathrm{OSeB}_{6} 10$-treated gilts. Unfortunately, our Se determination technique does not allow measurements at the embryonic level.

Brennan et al. (2011), studying the effects of OSe and MSe dietary supplementation on gene expression profiles in oviduct tissue from broiler-breeder hens, also found that, even without differences in tissue Se concentration, gene expression differed between the respective treatments. This would suggest that Se concentrations may not be always a reliable indicator of the impact of Se on physiological processes.

Although treatment-dependent DE was not observed, several genes of interest were identified in the methionine cycle and transsulfuration pathway, suggesting that PEBs are capable of synthesizing SeGPX. However, surprisingly, at this stage of development neither $\mathrm{MSeB}_{6} 10$ nor $\mathrm{OSeB}_{6} 10$ was able to over-stimulate SeGPX synthesis. These observations are consistent with Fortier et al. (2012), who showed that the SeGPX content in 30-day porcine embryos did not differ between MSe and OSe maternal supplementation. These intriguing results raise many hypothesis regarding Sec evolutionary events, Se metabolism, and selenoproteins synthesis.

Leinfelder et al. (1988) and Bock et al. (1991) proposed that during the evolution of Sec within the genetic code, UGA was initially a sense codon for this amino acid and that $\mathrm{Sec}$ was used not only for synthesis of SeGPX but widely for several enzymes. Later in the evolutionary process, oxygen was introduced into the atmosphere which selected against the use of Sec as this amino acid is oxygen-labile. Consequently, the global utilization of Sec decreased during evolution and became limited to anaerobic environments only. As the expanded blastocyst 
Table 7 Sulfur and Se antioxidation-related genes expressed in the porcine expanded blastocyst.

\begin{tabular}{|c|c|c|c|}
\hline GS & Description & $A$-value ${ }^{\mathrm{a}}$ & S.D. \\
\hline \multicolumn{4}{|c|}{ Common metabolism for Se and sulfur } \\
\hline MAT1A & $S$-adenosylmethionine synthetase isoform type 1 & 6.1 & 0.3 \\
\hline MAT2A & $S$-adenosylmethionine synthetase isoform type 2 & 9.1 & 1.8 \\
\hline$A H C Y$ & $S$-adenosylhomocysteine hydrolase & 9.5 & 1.0 \\
\hline$A H C Y L 1$ & $S$-adenosylhomocysteine hydrolase-like 1 & 6.3 & 0.5 \\
\hline AHCYL2 & $S$-adenosylhomocysteine hydrolase-like 2 & 6.4 & 0.4 \\
\hline $\mathrm{CTH}$ & Cystathionine gamma-lyase & 7.7 & 2.9 \\
\hline \multicolumn{4}{|c|}{ GSH synthesis, recycling, and utilization } \\
\hline$G C L C$ & Glutamate-cysteine ligase catalytic subunit & 8.0 & 3.8 \\
\hline GCLM & Gamma-glutamylcysteine synthetase regulatory subunit & 8.9 & 1.7 \\
\hline GSS & Glutathione synthase & 6.9 & 0.6 \\
\hline$G S R$ & Glutathione reductase & 7.0 & 0.8 \\
\hline GGT1 & Gamma-glutamyltransferase 1 & 6.5 & 1.0 \\
\hline GGT5 & Gamma-glutamyltransferase 5 & 6.5 & 0.6 \\
\hline GGT6 & Gamma-glutamyltransferase 6 & 6.2 & 0.4 \\
\hline GGT7 & Gamma-glutamyltransferase 7 & 6.2 & 0.3 \\
\hline GPX5 & Glutathione peroxidase 5 & 6.2 & 0.3 \\
\hline GPX8 & Glutathione peroxidase 8 & 6.2 & 0.5 \\
\hline GSTA1 & Glutathione $S$-transferase alpha 1 & 6.1 & 0.4 \\
\hline GSTA4 & Glutathione $S$-transferase alpha 4 & 7.3 & 0.9 \\
\hline GSTA5 & Glutathione $S$-transferase alpha 5 & 6.7 & 0.5 \\
\hline GSTCD & Glutathione $S$-transferase, C-terminal containing domain & 7.1 & 2.2 \\
\hline GSTK1 & Glutathione $S$-transferase kappa 1 & 7.1 & 0.5 \\
\hline GSTM1 & Glutathione $S$-transferase mu 1 & 6.6 & 0.8 \\
\hline GSTM3 & Glutathione $S$-transferase mu 3 & 7.7 & 1.7 \\
\hline GSTO1 & Glutathione $S$-transferase omega 1 & 9.4 & 1.8 \\
\hline GSTO2 & Glutathione $S$-transferase omega 2 & 7.6 & 0.8 \\
\hline GSTP1 & Glutathione $S$-transferase pi 1 & 9.8 & 2.4 \\
\hline GSTT1 & Glutathione $S$-transferase theta 1 & 6.2 & 1.0 \\
\hline GSTT4 & Glutathione $S$-transferase theta 4 & 6.0 & 0.3 \\
\hline GSTZ1 & Glutathione transferase zeta 1 & 6.3 & 0.3 \\
\hline MGST2 & Microsomal glutathione transferase 2 & 8.4 & 2.9 \\
\hline MGST3 & Microsomal glutathione transferase 3 & 7.7 & 0.7 \\
\hline PTGES & Prostaglandin E synthase & 9.5 & 2.4 \\
\hline PTGES2 & Prostaglandin E synthase 2 & 6.7 & 0.8 \\
\hline PTGES3 & Prostaglandin E synthase 3 & 9.8 & 2.9 \\
\hline \multicolumn{4}{|c|}{ Exclusive metabolism of SeGPX } \\
\hline SCLY & Selenocysteine lyase & 6.0 & 0.4 \\
\hline SEPHS2 & Selenophosphate synthetase 2 & 6.4 & 0.4 \\
\hline SARS & Seryl tRNA ligase & 6.9 & 0.9 \\
\hline SARS2 & Seryl tRNA ligase 2 & 6.1 & 0.5 \\
\hline PSTK & Phosphoseryl-tRNA kinase & 6.7 & 0.3 \\
\hline SEPSECS & Sep (O-phosphoserine) tRNA:SectRNA synthase & 6.2 & 0.3 \\
\hline EEFSEC & Eukaryotic elongation factor selenocysteine-tRNA specific & 6.2 & 0.2 \\
\hline SECISBP2 & Selenocysteine insertion sequence-binding protein 2 & 6.6 & 0.6 \\
\hline SECISBP2L & Selenocysteine insertion sequence-binding protein 2 like & 6.3 & 0.5 \\
\hline \multicolumn{4}{|c|}{ сен } \\
\hline SEPN1 & Selenoprotein $\mathrm{N}$, variant 1 & 6.1 & 0.2 \\
\hline SEPP1 & Selenoprotein $\mathrm{P}$, variant 1 & 6.1 & 0.4 \\
\hline DIO3 & lodothyronine 3 & 6.4 & 1.3 \\
\hline SELK & Selenoprotein K & 8.8 & 2.2 \\
\hline SELM & Selenoprotein M & 7.1 & 1.8 \\
\hline SELO & Selenoprotein $\mathrm{O}$ & 8.1 & 2.5 \\
\hline SELS & VCP-interacting membrane protein, variant 2 & 8.8 & 1.9 \\
\hline SELT & Selenoprotein T & 6.4 & 0.4 \\
\hline SELV & Selenoprotein V & 6.5 & 0.2 \\
\hline TXNRD1 & Thioredoxin reductase 1 & 6.6 & 0.6 \\
\hline TXNRD2 & Thioredoxin reductase 2 & 6.1 & 0.2 \\
\hline TXNRD3 & Thioredoxin reductase 3 & 7.0 & 0.9 \\
\hline GPX2 & Glutathione peroxidase 2 & 6.2 & 0.3 \\
\hline GPX3 & Glutathione peroxidase 3 & 7.0 & 1.2 \\
\hline GPX6 & Glutathione peroxidase 6 & 7.4 & 1.7 \\
\hline
\end{tabular}

${ }^{a}$ The level of gene expression was indicated by the average $A$-value reflecting spot intensity higher than the background intensity. Average $A$-value from dark-corner spot intensity was consider to be background (mean $A$-value $=6.0$ and s.D. $=0.3$ ).

develops under hypoxic and even almost anaerobic conditions (Fischer \& Bavister 1993), the possibility exists that Sec was required and used for global protein synthesis in preference to selenoproteins synthesis, as suggested by Gladyshev \& Kryukov (2001), in anaerobic organisms.

The enzymatic activity of many antioxidative enzymes in embryos is much lower than in adults, and thus, 


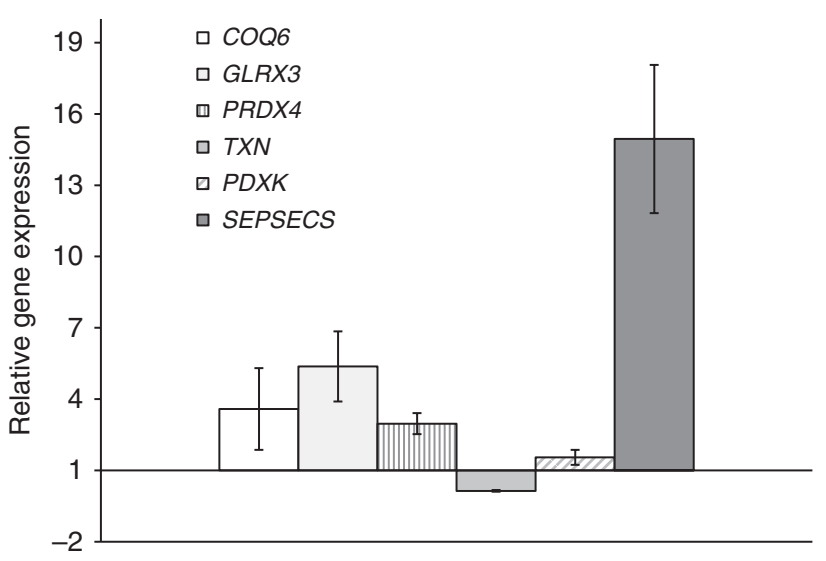

Figure 4 RT-qPCR expression trends for COQ6, GLRX3, PRDX4, TXN, $P D X K$, and SEPSECS in porcine expanded blastocysts recovered from $\mathrm{OSeB}_{6} 10$ supplemented gilts, shown as relative gene expression to CONT ( \pm s.E.M.). PPIA was used to normalize the mRNA expression levels. $\mathrm{OSeB}_{6} 10=$ basal diet supplemented with $0.3 \mathrm{mg} / \mathrm{kg}$ of Se-enriched yeast (Alltech, Inc.) and $10 \mathrm{mg} / \mathrm{kg}$ of hydro-chloride pyridoxine (P9755, Sigma-Aldrich).

embryos are particularly sensitive to oxidative damage (Parman et al. 1999, Winn \& Wells 1999). The SeGPX system is a major antioxidant complex in the organism, and is responsive to Se and $B_{6}$ status (Roy et al. 2011), because $\mathrm{B}_{6}$ catalyzes the conversion of SeMet to Sec, which is further incorporated into SeGPX and other selenoproteins. The RT-qPCR analysis revealed that SEPSECS (the gene that encodes a protein responsible for the last step in the synthesis of selenocysteinyl-tRNA $(\mathrm{Sec}))$ was upregulated in $\mathrm{OSeB}_{6} 10$ gilts. However, as this was the only SeGPX-related gene to be upregulated, it cannot be stated that this overall metabolic pathway was in fact over-stimulated.

In addition, Gardiner \& Reed (1995), studying the recovery of glutathione (GSH) in mouse preimplantation embryos, found that the blastocyst cannot convert sulfur-methionine into sulfur-cysteine via the cystathionine transsulfuration pathway. This is a relevant and critical finding for Se metabolism, because SeMet follows the sulfur-methionine biochemical pathway toward Sec (Sunde 1984). Thus, SeMet would not produce Sec and, therefore, might direct Se toward general protein synthesis or methylation. Se compounds methylation enzymes cystathionine gamma-lyase (CTH) and indolethylamine $\mathrm{N}$-methyltransferase (INMT), along with other general protein methylation enzymes glutamic-oxaloacetic transaminase 1 and 2 (GOT1 and GOT2), glutamic-pyruvate transaminase (GPT), betaine-homocysteine $S$-methyltransferase $(B H M T)$, and protein-L-isoaspartate $O$-methyltransferase (PCMT1) were not $\mathrm{DE}$, whereas several genes related with general elongation factors were upregulated and biological process related with translation, regulation of translation, and mitotic cell cycle was stimulated.
This finding reinforces the concept that, at this stage of development, Se is likely directed to the global protein synthesis in the PEB. The contribution of $B_{6}$ to this effect appeared important because when the comparison was made between $\mathrm{OSeB}_{6} 10$ vs $\mathrm{MSeB}_{6} 10$, few genes related with general elongation factors were upregulated and no biological process was selectively stimulated by $\mathrm{OSeB}_{6} 10$.

Se-glutathione peroxidase not only depends on Se and $\mathrm{B}_{6}$ but also on the availability of GSH for its enzymatic activity (Ufer \& Wang 2011). According to Yoshida et al. (1993), the amount of GSH in the porcine oocyte exceeds the needs for fertilization, but during pre-implantation development, embryonic GSH continuously decreases and reaches a nadir at the blastocyst stage, whereas endogenous ROSs are produced at their highest level at this time. These low GSH and high ROS levels are possibly required for normal differentiation (Pierce et al. 1991, Parchment 1993), in which ROS may act as an important regulatory system for apoptosis in the mouse blastocyst (Pierce et al. 1991). According to Gardiner \& Reed (1994), hydrogen peroxide in mouse blastocoel fluid causes apoptosis of pre-trophectodermal cells of the blastocyst, whereas the inner-cell-mass cells, destined to become the embryo, are protected from the toxic effects of hydrogen peroxide. The same authors suggest that this protection is performed via mechanisms that utilize GSH. This apparent control of embryo GSH production is illustrated by the present microarray and RT-qPCR data showing that TXN and GLRX (genes encoding proteins involved in recycling of GSH) were respectively down- and up-regulated in $\mathrm{OSeB}_{6} 10$ gilts.

Despite the lack of upregulated genes related with the transsulfuration pathway of methionine toward the SeGPX system, $\mathrm{OSeB}_{6} 10$ maternal supplementation differently expressed other genes related with cell antioxidant defense such as those of the thioredoxin (GLRX3, PRDX4, and TXN) and monooxygenase (COQ6) families. For the thioredoxin family, these genes are involved with key regulators of redox signaling and consequently of the intracellular effects of ROS (Fisher et al. 1999, Nordberg \& Arnér 2001, Ahsan et al. 2009). They are also critical for the control of DNA damage, cell proliferation, and differentiation (Laurent et al. 1964, Schenk et al. 1996, Saitoh et al. 1998) in PEB. For the monooxygenase family, COQ6 is required for the biosynthesis of ubiquinone, one of the most potent lipophilic antioxidants found to be involved in the protection of cell damage by ROS (Hyun et al. 2006).

The identification of these DE genes is coherent with the previously described stimulation of mitotic cell cycle as a biological process in $\mathrm{OSeB}_{6} 10$ gilts. In this way, it is noteworthy to mention that, although not statistically significant, the greatest number of viable embryos was collected from these gilts and this in absence of degenerated embryos (Table 3). Therefore, considering 
previous results reported by Fortier et al. (2012) in which enhanced 30-day embryos development was observed in OSe gilts without effect on embryo SeGPX activity, it can be hypothesized that these antioxidative defenses from the thioredoxin and monooxygenase families could act as supplementary mechanisms to the SeGPX system in PEB from $\mathrm{OSeB}_{6} 10$-supplemented sows and this may persist thereafter for at least the first third of gestation.

In conclusion, maternal dietary OSe supplementation with pyridoxine considerably stimulated the transcriptome of PEB as compared with unsupplemented gilts. For the comparison between sources of Se with equivalent supplemental pyridoxine, there was also an important response in terms of DE genes, but no specific biological process was identified. Porcine expanded blastocysts are potentially capable of synthesizing selenoproteins, including SeGPX; however, both Se sources with pyridoxine did not influence the SeGPX metabolic pathway at this stage.

In PEB from $\mathrm{OSeB}_{6} 10$ supplemented gilts, other members of the thioredoxin family, as well as ubiquinones, appear to complement the antioxidant defense and the regulation of cell proliferation. However, the mechanisms by which OSe combined with pyridoxine controls these processes remain to be explained.

\section{Supplementary data}

This is linked to the online version of the paper at http://dx.doi. org/10.1530/REP-14-0408.

\section{Declaration of interest}

The authors declare that there is no conflict of interest that could be perceived as prejudicing the impartiality of the research reported.

\section{Funding}

This study was supported by Alltech Biotechnology Center, Nicholasville, KY, USA; Groupe Ceres, Inc., Saint-Nicolas, QC, Canada; Natural Science and Engineering Research Council of Canada (NSERC) to G R Foxcroft and M K Dyck; and Agriculture and Agri-Food Canada. The platform information had been previously deposited and available on NCBI with Gene Expression Omnibus (GEO) ID: GPL14925. Data of this study was submitted to NCBI GEO Database (GSE51249).

\section{Acknowledgements}

The authors are grateful to M Guillette for her technical assistance, to the animal care team under supervision of $M$ Turcotte, and to S Methot for advice related with statistical analyses.

\section{References}

Agriculture Canada 1993 Recommended code of practice for care and handling of pigs. Publication No. 1771E. Agriculture Canada, Ottawa, ON, Canada

Ahsan MK, Lekli I, Ray D, Yodoi J \& Das DK 2009 Redox regulation of cell survival by the thioredoxin superfamily: an implication of redox gene therapy in the heart. Antioxidants \& Redox Signaling 11 2741-2758. (doi:10.1089/ars.2009.2683)

Benjamini Y \& Hochberg Y 1995 Controlling the false discovery rate: a practical and powerful approach to multiple testing. Journal of the Royal Statistical Society. Series B 57 289-300.

Bock A, Forchhammer K, Heider J, Leinfelder W, Sawers G, Veprek B \& Zinoni F 1991 Selenocysteine: the 21st amino acid. Molecular Microbiology 5 515-520. (doi:10.1111/j.1365-2958.1991.tb00722.x)

Brännström M, Mayrhofer G \& Robertson SA 1993 Localization of leukocyte subsets in the rat ovary during the periovulatory period. Biology of Reproduction 48 277-286. (doi:10.1095/biolreprod48.2.277)

Brennan KM, Crowdus CA, Cantor AH, Pescatore AJ, Barger JL, Horgan K, Xiao R, Power RF \& Dawson KA 2011 Effects of organic and inorganic dietary selenium supplementation on gene expression profiles in oviduct tissue from broiler-breeder hens. Animal Reproduction Science 125 180-188. (doi:10.1016/j.anireprosci.2011.02.027)

Canadian Council on Animal Care 2009 In Guide to the Care and Use of Experimental Animals. Ottawa, Ontario, Canada: CCAC [internet]. Available from: http://www.ccac.ca/documents/normes/lignes_directrices/ animaux_de_ferme.pdf

Driancourt MA, Martinat-Botté F \& Terqui M 1998 Contrôle du taux d'ovulation chez la truie: L'apport des modèles hyperprolifiques. INRA Productions Animales 11 221-226.

Eden E, Navon R, Steinfeld I, Lipson D \& Yakhini Z 2009 GOrilla: a tool for discovery and visualization of enriched GO terms in ranked gene lists. BMC Bioinformatics 10 48. (doi:10.1186/1471-2105-10-48)

Fischer B \& Bavister BD 1993 Oxygen tension in the oviduct and uterus of rhesus monkeys, hamsters and rabbits. Journal of Reproduction and Fertility 99 673-679. (doi:10.1530/jrf.0.0990673)

Fisher AB, Dodia C, Manevich Y, Chen JW \& Feinstein SI 1999 Phospholipid hydroperoxides are substrates for nonselenium glutathione peroxidase. Journal of Biological Chemistry 274 21326-21334. (doi:10. 1074/jbc.274.30.21326)

Fortier M-E, Audet I, Giguère A, Laforest J-P, Bilodeau J-F, Quesnel H \& Matte JJ 2012 Effect of dietary organic and inorganic selenium on antioxidant status, embryo development, and reproductive performance in hyperovulatory first-parity gilts. Journal of Animal Science $\mathbf{9 0}$ 231-240. (doi:10.2527/jas.2010-3340)

Fortune JE 1994 Ovarian follicular growth and development in mammals. Biology of Reproduction 50 225-232. (doi:10.1095/biolreprod50.2.225)

Freking BA, Leymaster KA, Vallet JL \& Christenson RK 2007 Number of fetuses and conceptus growth throughout gestation in lines of pigs selected for ovulation rate or uterine capacity. Journal of Animal Science 85 2093-2103. (doi:10.2527/jas.2006-766)

Gardiner CS \& Reed DJ 1994 Status of glutathione during oxidant-induced oxidative stress in the preimplantation mouse embryo. Biology of Reproduction 51 1307-1314. (doi:10.1095/biolreprod51.6.1307)

Gardiner CS \& Reed DJ 1995 Glutathione redox cycle-driven recovery of reduced glutathione after oxidation by tertiary-butyl hydroperoxide in preimplantation mouse embryos. Archives of Biochemistry and Biophysics 321 6-12. (doi:10.1006/abbi.1995.1361)

Giguère A, Fortier M-E \& Matte JJ 2005 Rapid, sensitive and versatile determination of selenium in different biological samples. Canadian Journal of Animal Science 85 533-536. (doi:10.4141/A05-044)

Gladyshev VN \& Kryukov GV 2001 Evolution of selenocysteine-containing proteins: significance of identification and functional characterization of selenoproteins. BioFactors 14 87-92. (doi:10.1002/biof.5520140112)

Gonzalez-Flores JN, Shetty SP, Dubey A \& Copeland PR 2013 The molecular biology of selenocysteine. Biomolecular Concepts 4 349-365. (doi:10.1515/bmc-2013-0007)

Guerin P, El Mouatassim S \& Menezo Y 2001 Oxidative stress and protection against reactive oxygen species in the preimplantation embryo and its surrounding. Human Reproduction Update 7 175-189. (doi:10.1093/humupd/7.2.175) 
Gunzler WA \& Flohe L 1985 Glutathione peroxidase. In Handbook of Methods for Oxygen Radical Research, 3rd edn, pp 285-290. Ed RA Greenwald. Boca Raton: CRC Press, Inc.

Hyun DH, Hernandez JO, Mattson MP \& de Cabo R 2006 The plasma membrane redox system in aging. Ageing Research Reviews 5 209-220. (doi:10.1016/j.arr.2006.03.005)

Konig R, Baldessari D, Pollet N, Niehrs C \& Eils R 2004 Reliability of gene expression ratios for cDNA microarrays in multiconditional experiments with a reference design. Nucleic Acids Research 32 e29. (doi:10.1093/nar/gnh027)

Laurent TC, Moore EC \& Reichard P 1964 Enzymatic synthesis of deoxyribonucleotides. IV. Isolation and characterization of thioredoxin, the hydrogen donor from Escherichia coli. Journal of Biological Chemistry 239 3436-3444.

Le Floc'h N, Gondret F, Matte JJ \& Quesnel H 2012 Towards amino acid recommendations for specific physiological and patho-physiological states in pigs. Proceedings of the Nutrition Society 71 425-432. (doi:10. 1017/S0029665112000560)

Leinfelder W, Zehelein E, Mandrand-Berthelot M-A \& Bock A 1988 Gene for a novel tRNA species that accepts L-serine and cotranslationally inserts selenocysteine. Nature 331 723-725. (doi:10.1038/331723a0)

Mahan DC, Brendemuhl JH, Carter SD, Chiba LI, Crenshaw TD, Cromwell GL, Dove CR, Harper AF, Hill GM, Hollis GR et al. 2005 Comparison of dietary selenium fed to grower-finisher pigs from various regions of the United States on resulting tissue Se and loin mineral concentrations. Journal of Animal Science 83 852-857.

Matte JJ, Pontier AA \& Sève B 1997 Effects of chronic parental pyridoxine and acute enteric tryptophan on pyridoxine status, glycemia and insulinemia stimulated by enteric glucose in weanling piglets. Canadian Journal of Animal Science 77 663-668. (doi:10.4141/A97-013)

Matte JJ, Girard CL \& Sève B 2001 Effects of long-term parenteral administration of vitamin $B_{6}$ on $B_{6}$ status and some aspects of the glucose and protein metabolism of early-weaned piglets. British Journal of Nutrition 85 11-21. (doi:10.1079/BJN2000221)

Niemann H, Carnwath JW \& Kues W 2007 Application of DNA array technology to mammalian embryos. Theriogenology 68 165-177. (doi:10.1016/j.theriogenology.2007.05.041)

Nordberg J \& Arnér ES 2001 Reactive oxygen species, antioxidants, and the mammalian thioredoxin system. Free Radical Biology \& Medicine 31 1287-1312. (doi:10.1016/S0891-5849(01)00724-9)

NRC 1998 Nutrient Requirements of Swine, 10th ed. Washington, DC: National Academy Press.

NRC 2012 Nutrient Requirements of Swine, 11th ed. Washington, DC: National Academy Press.

Orsi NM \& Leese HJ 2001 Protection against reactive oxygen species during mouse preimplantation embryo development: role of EDTA, oxygen tension, catalase, superoxide dismutase and pyruvate. Molecular Reproduction and Development 59 44-53. (doi:10.1002/mrd.1006)

Parchment RE 1993 The implications of a unified theory of programmed cell death, polyamines, oxyradicals and histogenesis in the embryo. International Journal of Developmental Biology 37 75-83.

Parman T, Wiley MJ \& Wells PG 1999 Free radical-mediated oxidative DNA damage in the mechanism of thalidomide teratogenicity. Nature Medicine 5 582-585. (doi:10.1038/8466)

Patterson J, Wellen A, Hahn M, Pasternak A, Lowe J, DeHaas S, Kraus D, Williams N \& Foxcroft G 2008 Responses to delayed estrus after weaning in sows using oral progestagen treatment. Journal of Animal Science $\mathbf{8 6}$ 1996-2004. (doi:10.2527/jas.2007-0440)

Pfaffl MW, Horgan GW \& Dempfle L 2002 Relative expression software tool (REST) for group-wise comparison and statistical analysis of relative expression results in real-time PCR. Nucleic Acids Research 30 e36. (doi:10.1093/nar/30.9.e36)

Pierce GB, Parchment RE \& Lewellyn AL 1991 Hydrogen peroxide as a mediator of programmed cell death in the blastocyst. Differentiation 46 181-186. (doi:10.1111/j.1432-0436.1991.tb00880.x)

Roy M, Audet I, Palin MF, Quesnel H, Guay F \& Matte JJ 2011 Dietary sources of selenium in nulliparous sows: the importance of vitamin B6 status for some aspects of antioxidant status and ovulation during the peri-estrus period. Journal of Animal Science 89 (e-suppl 1) 584.
Saitoh M, Nishitoh H, Fujii M, Takeda K, Tobiume K, Sawada Y, Kawabata M, Miyazono K \& Ichijo H 1998 Mammalian thioredoxin is a direct inhibitor of apoptosis signal regulating kinase (ASK) 1. EMBO Journal 17 2596-2606. (doi:10.1093/emboj/17.9.2596)

Schenk H, Vogt M, Dröge W \& Schulze-Osthoff K 1996 Thioredoxin as a potent costimulus of cytokine expression. Journal of Immunology 156 $765-771$.

Schrauzer GN 2000 Selenomethionine: a review of its nutritional significance, metabolism and toxicity. Journal of Nutrition 130 1653-1656.

Schrauzer GN 2003 The nutritional significance, metabolism and toxicology of selenomethionine. Advances in Food and Nutrition Research 47 73-112. (doi:10.1016/S1043-4526(03)47002-2)

Sheehan TM \& Gao M 1990 Simplified fluorometric assay of total selenium in plasma and urine. Clinical Chemistry 36 2124-2126.

Smyth GK 2005 Limma: linear models for microarray data. In Bioinformatics and Computational Biology Solutions Using $R$ and Bioconductor, pp 397-420. Eds R Gentleman, V Carey, W Huber, R Irizarry\& S Dudoit. New York: Springer.

Srivastava SK \& Beutler E 1973 A new fluorometric method for the determination of pyridoxal 5-phosphate. Biochimica et Biophysica Acta 304 765-773. (doi:10.1016/0304-4165(73)90223-7)

Sunde RA 1984 The biochemistry of selenoproteins. Journal of the American Oil Chemists' Society 61 1891-1900. (doi:10.1007/ BF02540827)

Svoboda M, Ficek R \& Drabek J 2008 Efficacy of organic selenium from Se-enriched yeast on selenium transfer from sows to piglets. Acta Veterinaria Brno 77 515-521. (doi:10.2754/avb200877040515)

Tsoi S, Zhou C, Grant JR, Pasternak JA, Dobrinsky J, Rigault P, Nieminen J, Sirard M-A, Robert C, Foxcroft GR et al. 2012 Development of a porcine (Sus scofa) embryo-specific microarray: array annotation and validation. BMC Genomics 13 370. (doi:10.1186/1471-2164-13-370)

Ufer C \& Wang CC 2011 The roles of glutathione peroxidases during embryo development. Frontiers in Molecular Neuroscience 4 1-14. (doi:10.3389/fnmol.2011.00012)

Van der Hoek KH, Maddocks S, Woodhouse CM, Van Rooijen N, Robertson SA \& Norman RJ 2000 Intrabursal injection of clodronate liposomes causes macrophage depletion and inhibits ovulation in the mouse ovary. Biology of Reproduction 62 1059-1066. (doi:10.1095/ biolreprod62.4.1059)

Vandesompele J, De Preter K, Pattyn F, Poppe B, Van Roy N, De Paepe A \& Speleman F 2002 Accurate normalization of real-time quantitative RT-PCR data by geometric averaging of multiple internal control genes. Genome Biology 3 Research0034. (doi:10.1186/gb-2002-3-7research0034)

Windisch W 2002 Interaction of chemical species with biological regulation of the metabolism of essential trace elements. Analytical and Bioanalytical Chemistry 372 421-425. (doi:10.1007/s00216-001-1117-6)

Winn LM \& Wells PG 1999 Maternal administration of super oxide dismutase and catalase in phenytoin teratogenicity. Free Radical Biology \& Medicine 26 266-274. (doi:10.1016/S0891-5849(98)00193-2)

Yasumoto K, Iwami K \& Yoshida M 1979 Vitamin B6 depedence of selenomethionine and selenite utilization for glutathione peroxidase in the rat. Journal of Nutrition 109 760-766.

Yoshida M, Ishigaki K, Nagai T, Chikyu M \& Pursel VG 1993 Glutathione concentration during maturation and after fertilization in pig oocytes: relevance to the ability of oocytes to form male pronucleus. Biology of Reproduction 49 89-94. (doi:10.1095/biolreprod49.1.89)

Zhou C, Dobrinsky J, Tsoi S, Foxcroft GR, Dixon WT, Stothard P, Verstegen J \& Dyck MK 2014 Characterization of the altered gene expression profile in early porcine embryos generated from parthenogenesis and somatic cell chromatin transfer. PLOS ONE 14 e91728. (doi:10.1371/journal.pone.0091728)

Received 12 August 2014

First decision 10 September 2014

Revised manuscript received 9 October 2014

Accepted 16 October 2014 